\begin{tabular}{l|l} 
Jurnal Eksplorasi Akuntansi & $\begin{array}{l}\text { ISSN : 2656-3649 (Online) } \\
\text { hol. 2, No 1, Seri D, Februari 2020, Hal 2362-2372:/jea.ppj.unp.ac.id/index.php/jea/issue/view/20 }\end{array}$
\end{tabular}

\title{
PENGARUH PROFITABILITAS, UKURAN PERUSAHAAN, DAN JENIS KAP TERHADAP PENGUNGKAPAN ASET BIOLOGIS
}

\author{
Usi Gustria $^{1}$, Nurzi Sebrina ${ }^{2}$ \\ ${ }^{1}$ Alumni Jurusan Akuntansi Fakultas Ekonomi Universitas Negeri Padang \\ ${ }^{2}$ Jurusan Akuntansi Fakultas Ekonomi Universitas Negeri Padang \\ *Korespondensi: usigustria09@gmail.com
}

\begin{abstract}
This study aims to see the effect of profitability, firm size, and type of public accounting firms to biological asset disclosure. The population in this study are all agricultural companies listed on the Indonesia Stock Exchange (IDX) that is as many as 32 companies. The sample in this research use sampling technique purposive sampling counted 13 company in 2016-2018. The analysis was done by using multiple regression model. The results of this study indicate that: (1) The Profitability has no effect on the disclosure of biological asset. (2) Firm size has no effect on biological asset disclosure. (3) type of public accounting firm effect on biological asset disclosure.
\end{abstract}

Keywords: Profitability, Firm Size, Type of Public Accounting Firm, and Biological Asset Disclosure.

How to cite (APA $6^{\text {th }}$ style):

Gustria, Usi \& Sebrina, Nurzi. (2020). Pengaruh Profitabilitas, Ukuran Perusahaan, dan Jenis KAP Terhadap Pengungkapan Aset Biologis. Jurnal Eksplorasi Akuntansi. 2(1), Seri D, 2362-2372.

\section{PENDAHULUAN}

Pada setiap usaha yang dilakukan, khususnya pada bidang agrikultural sudah pasti membutuhkan informasi yang berkaitan dengan keadaan aset agrikultural. Informasi yang berkualitas sangat diminati oleh pihak berkepentingan. Karena tingkat kualitas pengambilan keputusan terpengaruh oleh kualitas informasi yang disajikan oleh pihak perusahaan. Sehingga penyajian informasi harus andal, relavan, dan transparan. Bagi pihak eksternal perusahaan, laporan keuangan merupakan jendela informasi yang memungkinkan mereka melihat kondisi aset perusahaan tersebut (Fitriany,2001).

Dalam penyajian laporan keuangan semestinya harus disertai dengan pengungkapan. Analisis yang dilakukan oleh para investor tidak terlepas dari berbagai informasi yang disampaikan oleh perusahaan melalui pengungkapan dalam laporan keuangan tahunan perusahaan yang menggambarkan prospek perusahaan dan kinerja manajemen (Andi, 2009). Suwardjono (2008-580) menyebutkan tujuan pengungkapan adalah menyajikan informasi yang dipandang 
perlu untuk mencapai tujuan pelaporan keuangan dan untuk melayani berbagai pihak yang mempunyai kepentingan berbeda-beda.

Pengungkapan laporan keuangan sangat perlu untuk diperhatikan. Menurut Choi (2005) pengungkapan memungkinkan laporan keuangan memiliki kualitas yang tinggi sehingga dapat mempermudah investor dan pemakai untuk memahami dan membandingkan informasi yang disajikan. Pada saat ini pengungkapan wajib saja dipandang tidak memadai untuk mengetahui kinerja suatu perusahaan sehingga diperlukan pengungkapan yang lebih dengan alasan transparansi, namun dalam kenyataannya perusahaan sangat berhati - hati karena dalam pengungkapan laporan keuangan terdapat kondisi perusahaan yang lalu dan masa yang akan datang (Sefty, 2016).

Perusahaan disebutkan sangat menjaga kerahasiannya, sementara eksternal perusahaan menginginkan informasi yang lebih sehingga cenderung menuntut pengungkapan lebih. Tingginya kebutuhan informasi terhadap prospek perusahaan menimbulkan keinginan stakeholder menuntut manajeman untuk melakukan pengungkapan yang melebihi pengungkapan wajib (Noegraheni, 2005). Dampaknya adalah memunculkan suatu pertanyaan bagi peneliti. Pertanyaan yang muncul adalah (1) bagaimana sikap manajemen dalam menanggapi keinginan stakeholder dalam hal pengungkapan? (2) apa faktor yang mempengaruhi keputusan manajemen tersebut? Maka dari itu pengungkapan laporan keuangan adalah suatu topik yang menarik untuk dibahas kembali.

Aset biologis merupakan bagian yang terdapat pada perusahaan agrikultural. Perusahaan agrikultural memiliki aset yang berkarakteristik unik yang membedakan dengan aset pada perusahaan di sektor lain (Putri, 2014). Pembahasan mengenai aset biologis terbilang baru dalam sektor kajian akuntansi Indonesia. Standar khusus yang mengatur mengenai aset agrikultural dan aset biologis di Indonesia baru berlaku pada tanggal 1 Januari 2018. Bahkan, buku yang dipakai sebagai literasi dalam proses perkuliahan masih sangat minim membahas aset tersebut.

Aset biologis didefenisikan sebagai hewan atau tanaman hidup yang menghasilkan aset agrikultural (PSAK 69). Setiap tumbuhan dan hewan hidup yang menghasilkan aset agrikultural dapat disebut sebagai aset biologis. Aset tersebut disebut sebagai aset biologis karena mengalami transformasi biologis (Utomo dan Khumaidah, 2014). Sebagai contoh perusahaan memproduksi dan menjual susu sapi sebagai produk utama, maka sapi disebut sebagai aset biologis dan susu adalah aset agrikultural. Selain dari definisi, PSAK 69 juga telah menyajikan item - item yang harus ada dalam pengungkapan aset biologis, baik wajib maupun tambahan.

Standar mengharuskan pengungkapan aset biologis yang lebih, agar melahirkan suatu informasi yang andal dan akurat, sehingga tidak menyesatkan pemakai informasi. Karena, transformasi biologis memungkinkan informasi yang disajikan oleh perusahaan agrikultural lebih bias daripada perusahaan sektor lain, disebabkan nilai sebenarnya dari aset cenderung berubah seiring dengan adanya transformasi aset tersebut (Eltanto, 2014). Perusahaan diharuskan mematuhi segala peraturan yang berlaku tanpa terkecuali. Regulator memaksa perusahaan untuk menyampaikan sesuai aktivitas yang dilakukan, dengan maksud untuk merendahkan tingkat kesenjangan informasi antara manajemen dan investor (Healy dan Palepu, 2001). Maka dari itu, penelitian ini mencoba menguraikan faktor - faktor yang memungkinkan, mempengaruhi atau mendorong kelengkapan pengungkapan aset biologis. Karena dengan lengkapnya pengungkapan aset biologis, maka regulator telah mencapai maksud dan tujuan mereka untuk menurunkan kesenjangan informasi. 


\section{REVIU LITERATUR}

Penelitian Alfiani (2019) yang berjudul pengaruh biological asset intensity, ukuran perusahaan, pertumbuhan perusahaan, konsentrasi kepemilikan manajerial, dan jenis kap terhadap pengungkapan aset biologis (pada perusahaan agrikultur yang terdaftar di bursa efek indonesia periode 2014-2017). Hasil penelitian menunjukkan bahwa Biological asset intensity tidak berpengaruh terhadap pengungkapan aset biologis pada perusahaan agrikultur yang terdaftar di Bursa Efek Indonesia (BEI) periode 2014-2017. Ukuran perusahaan tidak berpengaruh terhadap pengungkapan aset biologis pada perusahaan agrikultur yang terdaftar di Bursa Efek Indonesia (BEI) periode 2014-2017. Pertumbuhan perusahaan tidak berpengaruh terhadap pengungkapan aset biologis pada perusahaan agrikultur yang terdaftar di Bursa Efek Indonesia (BEI) periode 2014-2017. Konsentrasi kepemilikan manajerial berpengaruh positif terhadap pengungkapan aset biologis pada perusahaan agrikultur yang terdaftar di Bursa Efek Indonesia (BEI) periode 20142017. Jenis KAP berpengaruh positif terhadap pengungkapan aset biologis pada perusahaan agrikultur yang terdaftar di Bursa Efek Indonesia (BEI) periode 2014-2017.

Penelitian Kusumadewi (2018) yang berjudul pengaruh biological asset intensity dan ukuran perusahaan terhadap pengungkapan aset biologis. Hasil penelitian menunjukkan bahwa secara parsial biological asset intensity berpengaruh terhadap pengungkapan aset biologis, sedangkan ukuran perusahaan tidak berpengaruh terhadap pengungkapan aset biologis. Secara simultan biological asset intensity dan ukuran perusahaan berpengaruh terhadap pengungkapan aset biologis.

Penelitian Sa'diyah dkk (2019) yang berjudul pengaruh biological Asset Intensity, Ukuran Perusahaan, dan Tingkat Internasionalisasi Terhadap Pengungkapan Aset Biologis (Pada Perusahaan Agrikultur Yang Terdaftar Di Bursa Efek Periode 2013-2017). Hasil penelitian menunjukkan bahwa secara parsial Biological Asset Intensity berpengaruh negatif signifikan terhadap pengungkapan aset biologis pada perusahaan agrikultur yang terdaftar di Bursa Efek Indonesia (BEI) periode 2013-2017, Ukuran Perusahaan tidak berpengaruh terhadap pengungkapan aset biologis pada perusahaan agrikultur yang terdaftar di Bursa Efek Indonesia (BEI) periode 2013-2017, dan Tingkat Internasionalisasi berpengaruh negatif signifikan terhadap pengungkapan aset biologis pada perusahaan agrikultur yang terdaftar di Bursa Efek Indonesia (BEI) periode 2013-2017. Hasil pengujian secara simultan menunjukkan bahwa Biological Asset Intensity, Ukuran Perusahaan, dan Tingkat Internasionalisasi berpengaruh terhadap pengungkapan aset biologis pada perusahaan agrikultur yang terdaftar di Bursa Efek Indonesia (BEI) periode 2013-2017.

Penelitian Duwu dan Daat (2018) pengaruh biological asset intensity, ukuran perusahaan, konsentrasi kepemilikan, jenis kap, dan profitabilitas terhadap biological asset disclosure (Pada Perusahaan Agrikultur Yang Terdaftar Di Bursa Efek Indonesia Periode 2012-2016). Hasil penelitian menunjukkan bahwa biological asset intensity yang diukur dengan membandingkan total aset biologis dengan total aset perusahaan berpengaruh terhadap biological asset disclosure, sehingga hipotesis pertama diterima, penelitian ini membuktikan bahwa ukuran perusahaan yang diukur dengan melogaritma naturalkan dari total aset berpengaruh terhadap biological asset disclosure, sehingga hipotesis kedua diterima, penelitian ini membuktikan bahwa konsentrasi kepemilikan yang diukur dengan membandingkan jumlah kepemilikan saham terbesar dengan jumlah saham yang beredar dikalikan dengan 100 tidak berpengaruh terhadap biological asset disclosure, sehingga hipotesis ketiga ditolak, penelitian ini membuktikan bahwa jenis KAP yang diukur dengan variabel dummy tidak berpengaruh terhadap biological asset disclosure, sehingga hipotesis keempat ditolak, penelitian ini membuktikan bahwa profitabilitas yang diukur dengan 
membandingkan total laba setelah pajak pada total aset tidak berpengaruh terhadap biological asset disclosure.

\section{METODE PENELITIAN}

Jenis penelitian ini adalah penelitian kausatif kuantitatif. Pengujian hipotesis dilakukan dengan menggunakan perhitungan statistik yang digunakan untuk menguji pengaruh variabel $\mathrm{X} 1$, $\mathrm{X} 2$, dan X3 terhadap Y. Verikatif berarti meguji teori dengan pengujian suatu hipotesis apakah diterima atau tidak". Dalam penelitian ini melihat pengaruh Profitabilitas, Ukuran Perusahaan, dan Jenis KAP Terhadap Pengungkapan Aset Biologis.

\section{HASIL DAN PEMBAHASAN Analisis Data Statistik Deskriptif}

Tabel 1

Hasil Statistik Deskriptif

\begin{tabular}{|c|c|c|c|c|c|c|c|c|}
\hline & \multirow{2}{*}{$\begin{array}{c}\mathrm{N} \\
\text { Statistic }\end{array}$} & \multirow{2}{*}{$\begin{array}{c}\text { Range } \\
\text { Statistic }\end{array}$} & \multirow{2}{*}{$\begin{array}{l}\text { Minimum } \\
\text { Statistic }\end{array}$} & \multirow{2}{*}{$\begin{array}{l}\text { Maximum } \\
\text { Statistic }\end{array}$} & \multicolumn{2}{|c|}{ Mean } & \multirow{2}{*}{$\begin{array}{c}\text { Std. Deviation } \\
\text { Statistic }\end{array}$} & \multirow{2}{*}{$\begin{array}{l}\text { Variance } \\
\text { Statistic }\end{array}$} \\
\hline & & & & & Statistic & Std. Error & & \\
\hline pengungkapan & 39 & 25,00 & 5,00 & 30,00 & 16,5897 & 1,03104 & 6,43885 & 41,459 \\
\hline jenis_KAP & 39 & 1,00 &, 00 & 1,00 & ,4103 & 07979 & ,49831 & ,248 \\
\hline Profitabilitas & 39 & 58,77 & $-31,87$ & 26,90 & 3,1227 & 1,72283 & 10,75905 & 115,757 \\
\hline ukuran_perusahaan & 39 & 1,97 & 5,47 & 7,44 & 6,6252 & ,08497 &, 53065 & ,282 \\
\hline Valid N (listwise) & 39 & & & & & & & \\
\hline
\end{tabular}

Berdasarkan tabel 1 dapat diketahui bahwa jumlah sampel yang digunakan dalam penelitian ini yaitu sebanyak 39 sampel penelitian.

\section{Uji Asumsi Klasik Uji Normalitas}

Tabel 2. Hasil Uji Normalitas

\begin{tabular}{llr}
\multicolumn{2}{|c}{ One-Sample Kolmogorov-Smirnov Test } \\
$\begin{array}{llr}\text { Unstandardized } \\
\text { Residual }\end{array}$ \\
\hline $\mathrm{N}$ & Mean & 39 \\
\cline { 2 - 3 } Normal Parameters & Std. Deviation &, 0000000 \\
\hline Most Extreme Differences & Absolute & 5,01214379 \\
\cline { 2 - 3 } & Positive &, 106 \\
\cline { 2 - 3 } & Negative &,- 079 \\
\hline Test Statistic & &, 106 \\
\hline Asymp. Sig. (2-tailed) & &, $200^{\text {c,d }}$ \\
\hline $\begin{array}{l}\text { a. Test distribution is Normal. } \\
\text { b. Calculated from data. } \\
\text { c. Lilliefors Significance Correction. } \\
\text { d. This is a lower bound of the true significance. } \\
\text { d. This }\end{array}$
\end{tabular}


Berdasarkan tabel 2, uji normalitas data pada penelitian ini yaitu nilai Kolmogorov-Smirnov sebesar 0,106 dan nilai signifikan 0,05 <0,200, dapat dinilai bahwa data telah terdistribusi secara normal.

\section{Uji Multikolinearitas}

Tabel 3. Hasil Uji Multikolinearitas

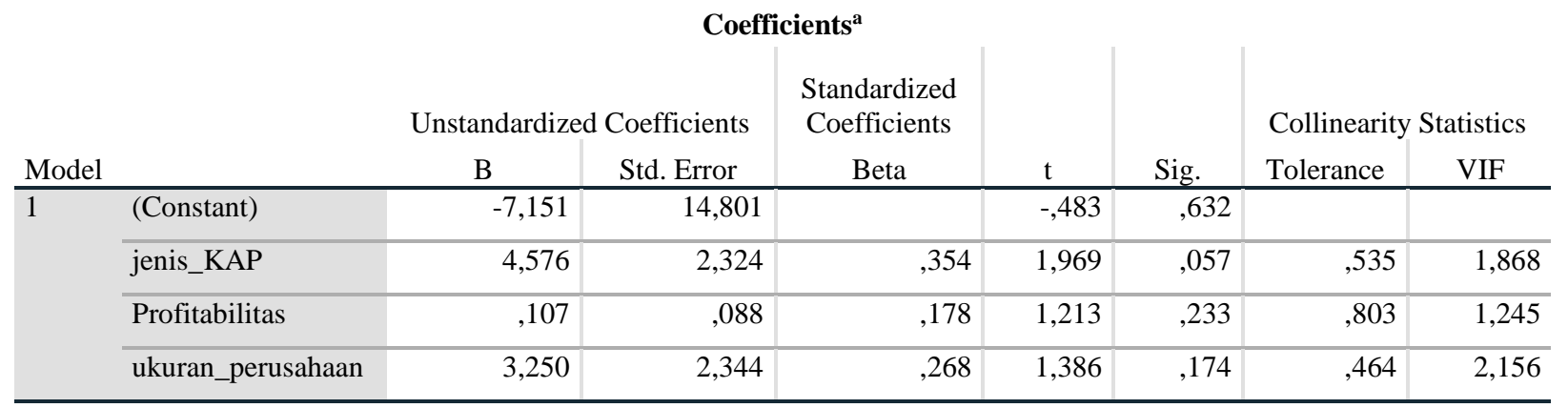

a. Dependent Variable: pengungkapan aset biologis

Berdasarkan tabel 3, uji multikolinearitas data pada penelitian ini yaitu nilai tolerance pada variabel profitabilitas sebesar 0,803 dan nilai VIF sebesar 1,254. Nilai tolerance pada variabel ukuran perusahaan sebesar 0,464 dan nilai VIF sebesar 2,156. Nilai tolerance pada variabel jenis KAP sebesar 0,535 dan nilai VIF sebesar 1,868. Dapat disimpulkan bahwa tidak terdapat gejala multikolinearitas antar variabel independen.

\section{Uji Autokorelasi}

\begin{tabular}{|c|c|c|c|c|c|}
\hline \multicolumn{6}{|c|}{$\begin{array}{c}\text { Tabel 4. Hasil Uji Autokorelasi } \\
\text { Model Summaryb }\end{array}$} \\
\hline Model & $\mathrm{R}$ & R Square & $\begin{array}{l}\text { Adjusted R } \\
\text { Square }\end{array}$ & $\begin{array}{l}\text { Std. Error of the } \\
\text { Estimate }\end{array}$ & Durbin-Watson \\
\hline 1 &, $628^{a}$ & ,394 &, 342 & 5,22253 & 1,504 \\
\hline
\end{tabular}

Dari tabel 4 dapat disimpulkan bahwa data dalam penelitian ini tidak terjadi gejala autokorelasi karena nilai Durbin-Watsonnya 1,504.

\section{Uji Heteroskedasitas}

Tabel 5. Hasil Uji Heteroskedasitas

\begin{tabular}{|c|c|c|c|c|c|c|c|c|}
\hline \multicolumn{9}{|c|}{ Coefficients $^{\mathrm{a}}$} \\
\hline \multirow[b]{2}{*}{ Model } & & \multicolumn{2}{|c|}{$\begin{array}{l}\text { Unstandardized } \\
\text { Coefficients }\end{array}$} & \multirow{2}{*}{$\begin{array}{c}\text { Standardized } \\
\text { Coefficients } \\
\text { Beta }\end{array}$} & \multirow[b]{2}{*}{$\mathrm{t}$} & \multirow[b]{2}{*}{ Sig. } & \multicolumn{2}{|c|}{ Collinearity Statistics } \\
\hline & & $\mathrm{B}$ & Std. Error & & & & Tolerance & VIF \\
\hline 1 & (Constant) & $-7,151$ & 14,801 & &,- 483 &, 632 & & \\
\hline & jenis_KAP & 4,576 & 2,324 & ,354 & 1,969 & 057 &, 535 & 1,868 \\
\hline
\end{tabular}




\begin{tabular}{l|r|r|r|r|r|r|r}
\hline Profitabilitas &, 107 &, 088 &, 178 & 1,213 &, 233 &, 803 & 1,245 \\
\hline $\begin{array}{l}\text { ukuran_perus } \\
\text { ahaan }\end{array}$ & 3,250 & 2,344 &, 268 & 1,386 &, 174 &, 464 & 2,156 \\
\hline
\end{tabular}

a. Dependent Variable: pengungkapan aset biologis

Pada hasil pengolahan data tabel 5 dapat disimpulkan bahwa nilai Sig. dari variabel profitabilitas yaitu 0,233; variabel ukuran perusahaan 0,174; dan untuk variabel jenis KAP 0,057; maka dapat disimpulkan tidak terjadi heterokedastisitas dalam sampel penelitian ini dan sampel penelitian ini layak untuk diteliti.

\section{Uji Kelayakan Model}

\section{Koefisien Determinasi (Ajusted $\boldsymbol{R}^{2}$ )}

\section{Tabel 6. Hasil Analisis Koefisien Determinasi}

\begin{tabular}{|c|c|c|c|c|c|}
\hline \multicolumn{6}{|c|}{ Model Summary ${ }^{b}$} \\
\hline Model & $\mathrm{R}$ & R Square & $\begin{array}{l}\text { Adjusted R } \\
\text { Square }\end{array}$ & $\begin{array}{l}\text { Std. Error of the } \\
\text { Estimate }\end{array}$ & Durbin-Watson \\
\hline 1 &, $628^{\mathrm{a}}$ & ,394 & ,342 & 5,22253 & 1,504 \\
\hline
\end{tabular}

Berdasarkan tabel 6 dapat dilihat bahwa nilai koefisien determinasi (Adjusted $R^{2}$ ) yaitu sebesar 0,342 . Sebesar $34 \%$ variabel nilai perusahaan dapat dijelaskan oleh variabel profitabilitas, ukuran perusahaan dan jenis KAP, sedangkan sisanya sebesar 66\% dijelaskan oleh faktor-faktor lain yang tidak diketahui dan tidak termasuk dalam analisis regresi berganda pada penelitian ini.

\section{Uji F}

\begin{tabular}{|c|c|c|c|c|c|c|}
\hline \multirow[b]{2}{*}{ Model } & \multicolumn{6}{|c|}{$\begin{array}{c}\text { Tabel 7. Hasil Uji F } \\
\text { ANOVA }^{\mathrm{a}}\end{array}$} \\
\hline & & Sum of Squares & Df & Mean Square & $\mathrm{F}$ & Sig. \\
\hline \multirow[t]{3}{*}{1} & Regression & 620,816 & 3 & 206,939 & 7,587 &, $000^{\mathrm{b}}$ \\
\hline & Residual & 954,620 & 35 & 27,275 & & \\
\hline & Total & 1575,436 & 38 & & & \\
\hline
\end{tabular}

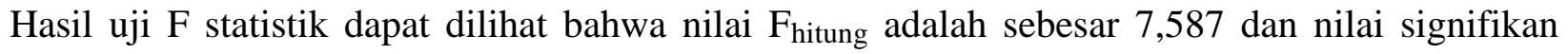
sebesar 0,000. Hal ini menunjukkan nilai $F_{\text {hitung }}(7,587)>F_{\text {tabel }}(2,901)$ dan sig $(0,001)<\alpha(0,05)$, sehingga dapat disimpulkan variabel profitabilitas, ukuran perusahaan dan jenis KAP berpengaruh signifikan secara simultan (bersama-sama) terhadap nilai perusahaan serta persamaan regresi yang digunakan dalam penelitian ini dapat diandalkan. 
Tabel 8. Hasil Analisis Regresi Berganda

\begin{tabular}{|c|c|c|c|c|c|c|c|c|}
\hline \multicolumn{9}{|c|}{ Coefficients $^{a}$} \\
\hline \multirow{3}{*}{\multicolumn{2}{|c|}{ Model }} & \multirow{2}{*}{\multicolumn{2}{|c|}{$\begin{array}{l}\text { Unstandardized } \\
\text { Coefficients }\end{array}$}} & \multirow{3}{*}{$\begin{array}{c}\text { Standardized } \\
\text { Coefficients } \\
\text { Beta }\end{array}$} & \multirow[b]{3}{*}{$\mathrm{t}$} & \multirow[b]{3}{*}{ Sig. } & \multirow{2}{*}{\multicolumn{2}{|c|}{ Collinearity Statistics }} \\
\hline & & & & & & & & \\
\hline & & B & Std. Error & & & & Tolerance & VIF \\
\hline \multirow[t]{4}{*}{1} & (Constant) & $-7,151$ & 14,801 & &,- 483 & 632 & & \\
\hline & jenis_KAP & 4,576 & 2,324 & ,354 & 1,969 & ,057 &, 535 & 1,868 \\
\hline & Profitabilitas & ,107 & ,088 &, 178 & 1,213 & ,233 &, 803 & 1,245 \\
\hline & ukuran_perusahaan & 3,250 & 2,344 & 268 & 1,386 &, 174 & ,464 & 2,156 \\
\hline
\end{tabular}

Berdasarkan pengolahan data statistik pada tabel 4.12 diperoleh penurunan regresi linear berganda sebagai berikut:

$$
\mathrm{pab}=-7,151+0,107 \mathrm{pf}+3,25 \mathrm{up}+4,576 \mathrm{jk}
$$

Angka yang dihasilkan dari pengujian tersebut dijelaskan sebagai berikut:

1) Konstanta (a)

Nilai konstanta yang diperoleh sebesar $-7,151$. Hal ini berarti bahwa tanpa adanya pengaruh variabel profitabilitas, ukuran perusahaan dan jenis KAP berpengaruh maka nilai pengungkapan aset biologis akan sebesar 7,151.

2) Koefisien Regresi $(\beta) X_{1}$

Nilai koefisien regresi variabel profitabilitas sebesar 0,107 . Hal ini menunjukkan bahwa setiap peningkatan satu satuan tingkat profitabilitas akan mengakibatkan peningkatan pengungkapan aset biologis sebesar 0,107 dengan anggapan variabel bebas lainnya tetap.

3) Koefisien Regresi $(\beta) X_{2}$

Nilai koefisien regresi variabel ukuran perusahaan sebesar 3,25. Hal ini menunjukkan bahwa setiap peningkatan satu satuan ukuran perusahaan akan meningkatkan nilai perusahaan sebesar 3,25 dengan anggapan variabel bebas lainnya tetap.

4) Koefisien Regresi $(\beta) X_{3}$

Nilai koefisien regresi variabel kepemilikan asing sebesar 4,576. Hal ini menunjukkan bahwa setiap peningkatan satu satuan jenis KAP akan meningkatkan pengungkapan aset biologis sebesar 4,576 dengan anggapan variabel bebas lainnya tetap.

\section{Uji Hipotesis}

$\begin{array}{cc}\text { Tabel 9. Hasil Uji Parsial }(t \text { Test }) \\ \text { Unstandardized } & \text { Standardized } \\ \text { Coefficients } & \text { Coefficients }\end{array}$

\begin{tabular}{|c|c|c|c|c|c|c|c|c|}
\hline \multirow{2}{*}{\multicolumn{2}{|c|}{ Model }} & \multirow[b]{2}{*}{ B } & \multicolumn{3}{|c|}{ Beta } & & \multicolumn{2}{|c|}{ Collinearity Statistics } \\
\hline & & & Std. Error & & $\mathrm{t}$ & Sig. & Tolerance & VIF \\
\hline \multirow[t]{4}{*}{1} & (Constant) & $-7,151$ & 14,801 & &,- 483 & ,632 & & \\
\hline & jenis_KAP & 4,576 & 2,324 & ,354 & 1,969 & 057 & ,535 & 1,868 \\
\hline & Profitabilitas & , 107 & ,088 &, 178 & 1,213 & ,233 & ,803 & 1,245 \\
\hline & ukuran_perusahaan & 3,250 & 2,344 & ,268 & 1,386 & ,174 & ,464 & 2,156 \\
\hline
\end{tabular}


1. Pengujian Hipotesis Pertama $\left(\mathrm{H}_{1}\right)$

Variabel profitabilitas memiliki nilai thitung $1,213<t_{\text {tabel }} 1,75$ dan nilai sig $(0,233)>\alpha(0,05)$ serta nilai koefisien $\beta$ sebesar 0,107. Variabel profitabilitas tidak berpengaruh terhadap pengungkapan aset biologis, dapat disimpulkan bahwa Hipotesis 1 ditolak.

2. Pengujian Hipotesis Kedua $\left(\mathrm{H}_{2}\right)$

Variabel ukuran perusahaan memiliki nilai $t_{\text {hitung }} 1,386<\mathrm{t}_{\text {tabel }} 1,75$ dan nilai sig $(0,174)>\alpha$ $(0,05)$ serta nilai koefisien $\beta$ sebesar 3,25 . Variabel ukuran perusahaan tidak berpengaruh terhadap pengungkapan aset biologis, dapat disimpulkan bahwa Hipotesis 2 ditolak.

3. Pengujian Hipotesis Ketiga $\left(\mathrm{H}_{3}\right)$

Variabel jenis KAP memiliki nilai $t_{\text {hitung }} 1,969>t_{\text {tabel }} 1,75$ dan nilai sig $(0,57)<\alpha(0,05)$ serta nilai koefisien $\beta$ sebesar 4,576. Variabel jenis KAP berpengaruh positif terhadap pengungkapan aset biologis, dapat disimpulkan bahwa Hipotesis 3 diterima.

\section{Pembahasan}

\section{Pengaruh Profitabilitas Terhadap Pengungkapan Aset Biologis}

Berdasarkan hasil analisis statistik dalam penelitian ini, ditemukan bahwa profitabilitas tidak berpengaruh terhadap pengungkapan aset biologis. Hasil ini dapat diartikan bahwa pengungkapan aset biologis yang dilaporkan pada laporan tahunan atau dalam laporan keberlanjutan perusahaan agrikultur tidak dipengaruhi oleh Return On Asset (ROA) perusahaan yang menjadi pengukuran untuk profitabilitas dalam penelitian ini.

\section{Pengaruh Ukuran Perusahaan Terhadap Pengungkapan Aset Biologis}

Berdasarkan hasil analisis statistik dalam penelitian ini, ditemukan bahwa ukuran perusahaan tidak berpengaruh terhadap pengungkapan aset biologis. Hasil ini dapat disimpulkan bahwa pengungkapan aset biologis yang dilaporkan pada laporan tahunan atau dalam laporan keberlanjutan perusahaan agrikultur tidak dipengaruhi oleh ukuran perusahaan agrikultur tersebut.

\section{Pengaruh jenis KAP terhadap pengungkapan aset biologis}

Berdasarkan hasil analisis statistik dalam penelitian ini, ditemukan bahwa jenis KAP berpengaruh positif terhadap pengungkapan aset biologis. Hasil penelitian ini memberikan bukti empiris bahwa perusahaan yang menggunakan jasa KAP big four di Indonesia untuk mengaudit laporan keuangannya cenderung mengungkapkan aset biologis secara lebih luas dalam laporan tahunan dan laporan keberlanjutan perusahaan.

\section{SIMPULAN, KETERBATASAN DAN SARAN Simpulan}

Penelitian ini bertujuan untuk melihat seberapa besar pengaruh profitabilitas, ukuran perusahaan dan jenis KAP terhadap luas pengungkapan aset biologis pada perusahaan agrikultur yang terdaftar di Bursa Efek Indonesia (BEI) pada tahun 2016 sampai tahun 2018. Berdasarkan hasil temuan penelitian dan pengujian hipotesis yang diajukan sebelumnya dapat disimpulkan bahwa profitabilitas tidak berpengaruh signifikan terhadap luas pengungkapan aset biologis. Pengungkapan aset biologis yang dilakukan perusahaan tidak dipengaruhi oleh penilaian ROA (Return On Asset) yang diikuti perusahaan yang menjadi pengukuran untuk profitabilitas pada penelitian ini.

Ukuran perusahaan tidak berpengaruh signifikan terhadap luas pengungkapan aset biologis. Pengungkapan aset biologis yang dilakukan perusahaan tidak dipengaruhi oleh penilaian logaritma 
natural aset yang diikuti perusahaan yang menjadi pengukuran untuk ukuran perusahaan pada penelitian ini, sedangkan jenis KAP berpengaruh positif terhadap luas pengungkapan aset biologis. Perusahaan yang menggunakan jasa audit laporan keuangan menggunakan jasa KAP big four di Indonesia akan cenderung mengungkapkan aset biologis yang lebih luas didalam laporan keuangannya.

\section{Keterbatasan}

1. Unsur subjektivitas dalam menentukan indeks pengungkapan sukarela. Indeks pengungkapan sukarela disebabkan oleh karena tidak adanya ketentuan baku yang dapat dijadikan acuan, sehingga penentuan indeks pengungkapan sukarela dapat berbeda untuk setiap peneliti.

2. Nilai adjusted $R$-Square yaitu sebesar $34,2 \%$ menunjukkan bahwa masih banyak variabel lain yang memiliki kontribusi besar dalam mempengaruhi luas pengungkapan sukarela pada laporan tahunan perusahaan.

3. Penelitian sampel dalam penelitian ini adalah purposive sampling. Keunggulan metode ini adalah peneliti dapat memilih sampel yang tepat, sehingga peneliti akan memperoleh data yang memenuhi kriteria untuk diuji. Penggunaan metode purposive sampling mengakibatkan pada kurangnya kemampuan generalisasi dari hasil penelitian

\section{Saran}

1. Bagi penelitian selanjutnya yang tertarik untuk meneliti judul yang sama sebaiknya mempertimbangkan untuk mengubah metode penelitian kuantitatif menjadi metode kualitatif.

2. Melakukan perluasan sampel penelitian untuk memperoleh data yang lebih ter-generalisasi.

\section{DAFTAR PUSTAKA}

Alfiani, Linda kurnia. (2019). "Pengaruh Biological Asset Intensity, Ukuran Perusahaan, Pertumbuhan Perusahaan, Konsentrasi Kepemilikan Manajerial, dan Jenis KAP Terhadap Pengungkapan Aset Biologis". Skripsi. Universitas Muhammadiyah Yogyakarta.

Amelia, Frida. (2017). "Pengaruh Biological Asset Intensity, Ukuran Perusahaan, Konsentrasi Kepemilikan, dan Jenis KAP Terhadap Pengungkapan Aset Biologis". Tesis. Universitas Andalas.

Barako, D., et al. (2006). "Factors Influencing Voluntary Corporate Disclosure by Kenyan Companies" Corporate Governance: An International Review, 14 (2), 107-125.

Campbell, D., et al. (2003), "Voluntary social reporting in three FTSE sectors: a comment on perception and legitimacy", Accounting, Auditing \& Accountability Journal, 16 (4): 558-581.

Campbell, D.J. (2000). "Legitimacy theory or managerial reality construction. Corporate social disclosure in Marks \& Spencer corporate reports, 1969-1997”, Accounting Forum, 24 (1): 80-100.

Choi, F. 2005. International Accounting. New Jersey: Prentice Hall

Christiawan, Rafika A. Putri. 2014. "Pengaruh Profitabilitas, Likuiditas, dan Leverage Terhadap Pengungkapan Corporate Social Responsibility (Studi Pada Perusahaan-perusahaan yang Mendapat Penghargaan ISRA dan Listed (Go-Public) di Bursa Efek Indonesia (BEI) 20102012)". Business Accounting Review 2 (1). Universitas Kristen Petra.

Dewan Standar Akuntansi Keuangan Ikatan Akuntansi Indonesia. 2018. Standar Akuntansi Keuangan. Jakarta: Ikatan Akuntansi Indonesia. 
Duwu, Marselina Inggrid, Sylvia Christina Daat, Hastutie N. A. 2018. "Pengaruh Biological Asset Intensity, Ukuran Perusahaan, Konsentrasi Kepemilikan, Jenis KAP, dan Profitabilitas Terhadap Biological Asset Disclosure”. Jurnal Akuntansi \& Keuangan Daerah. 13 (2): 5675.

Eltanto, D. P. 2014. Perlakuan Akuntansi dan PPh Atas Industri Agrikultur. Tax \& Accounting Review, 4 (1).

Fahmi, Irham. 2012. Analisis Kinerja Keuangan: Panduan Bagi Akademisi, Manajer, dan Investor Untuk Menilai dan Menganalisis Bisnis Dari Aspek Keuangan. Bandung: Alfabeta.

Fitriany. 2001. "Signifikansi Perbedaan Tingkat Kelengkapan Pengungkapan Wajib dan Sukarela pada Laporan Keuangan Perusahaan Publik yang Terdaftar di Bursa Efek Jakarta". Simposium Nasional Akuntansi IV. Bandung.

Freeman, E., \& McVea, J. 2001. "A Stakeholder Approach to Strategic Management". SSRN Electronic Journal, 1(1): 276.

Harahap, S.S. 2011. Teori Akuntansi. Jakarta: Rajawali Pers.

Healy, Paul M., and Krishna G. Palepu. 2001. "Information Asymmetry, Corporate Disclosure, and the Capital Markets: A Review of the Empirical Literature Disclosure". Journal of Accounting and Economics, 31 (1-3): 405-440

Hodgdon, et al. 2009. "Compliance with International Financial Reporting Standards and Auditor Choice: New Evidence on the Importance of the Statutory Audit". The International Journal of Accounting. Vol 44: 3355.

Kartika, Andi dan Hersugondo. 2009. "Faktor - Faktor Yang Mempengaruhi Kelengkapan Pengungkapan Laporan Keuangan Pada Perusahaan yang termasuk kategori LQ45 Yang Terdaftar di Bursa Efek Indonesia". Dalam Kajian Akuntansi, 1 (1): 29-47.

Korompis, C.W.M.. 2016. “Analisis Perlakuan Akuntansi Agrikultur Pada Petani Kelapa Pada Desa di Daerah Likupang Selatan : Dampak Rencana Penerapan ED PSAK NO. 69 Tentang Agrikultur".

Kusumadewi, Ayu Andari. 2018. "Pengaruh Biological Asset Intensity dan Ukuran Perusahaan Terhadap Pengungkapan Aset Biologis". Skripsi. Universitas Pasundan.

Noegraheni L. 2005. "Pengaruh Karakteristik Perusahaan Terhadap Kualitas Pengungkapan Sukarela Dalam Laporan Tahunan Pada Perusahaan Publik Non Industri Keuangan Di Bursa Efek Jakarta". Dalam Equity, 2(1): 61-80.

Nugroho, W. A. 2012. Pengaruh Profitabilitas, Likuiditas dan Leverage terhadap Nilai Perusahaan (Studi pada Perusahaan Sektor Manufaktur Di BEI Periode 2008-2011). Jurnal Universitas Muhammadiyah Surakarta: 30-55.

Nuryaman. 2009. "Pengaruh Konsentrasi Kepemilikan, Ukuran Perusahaan, dan Mekanisme Corporate Governance terhadap Pengungkapan Sukarela". Jurnal Akutansi dan Keuangan Indonesia. 6(1): 89-116.

Pearce, John A dan Richard B. Robinson. 2008. "Manajemen Strategis: Formulasi, Implementasi, dan Pengendalian". Jakarta: Salemba Empat.

Putri, Sulistyorini Rafika. 2014. "Analisis Perbandingan Pelaporan dan Pengungkapan Aset Biologis sebelum dan Setelah Penerapan IAS 41 pada PT. Astra Agro Lestari”. Universitas Negeri Surabaya.

Sa'diyah, Lentina Diah Jamilatus dkk. 2019. "Pengaruh Biological Asset Intensity, Ukuran Perusahaan, dan Tingkat Internasionalisasi Terhadap Pengungkapan Aset Biologis". Progress Conference. Vol. 2: 2622-3031. 
Sefty, Dien dkk. (2016). "Pengaruh Ukuran Perusahaan dan Kepemilikan Manajerial Terhadap Pengungkapan Laporan Keuangan”. Jurnal Akuntansi. 3 (2): 2339-2436.

Sugiono, Arief dan Untung, Edy. (2008). Panduan Praktis Dasar Analisa Laporan Keuangan: Pengetahuan Dasar Bagi Mahasiswa dan Praktisi Perbankan. Jakarta: Grasindo.

Suwardjono. (2008). Teori Akuntansi. Edisi Ketiga. Yogyakarta: BPFE.

Utomo, R. dan Khumaidah, N.L. (2014). "Perlakuan akuntansi aset biologis (tanaman kopi) pada PT. Wahana Graha Makmur - Surabaya”. Gema Ekonomi Jurnal Fakultas Ekonomi, 3 (1).

Wijayati, Fitri Laela dan Retno Wulandari. (2018). "Analisis Perlakuan Akuntansi Aset Biologis Pada Perusahaan Sektor Agrikultural Subsektor Perkebunan Yang Terdaftar Di Bursa Efek Indonesia". Riset Akuntansi dan Keuangan Indonesia. 3 (2).

Yurniwati, Amsal Djunid, Frida Amelia. (2018). "Effect of biological Asset Intensity, Company Size, Ownership Concentration, and Type Firm against Biological Assets Disclosure". The Indonesian Journal Of Accounting Research, 21 (1): 121 - 146. 